\title{
Recovery of Scenic Beauty of a Lake in Urban Park from Environmental Diagnosis and Implantation of Mitigating Measures
}

\author{
João Alexandre Saviolo Osti1,2,3, Clovis Ferreira Do Carmo ${ }^{3,4}$, Marcos Cerqueira ${ }^{3,4}$, \\ Maria Teresa Duarte Giamas ${ }^{3,4}$, Ana Carolina Peixoto ${ }^{3,5}$, Cacilda Thais Janson Mercante ${ }^{3,4}$ \\ ${ }^{1}$ Pesquisador Associado ao Instituto de Pesca, São Paulo, Brasil \\ ${ }^{2}$ Professor Colaborador à Universidade Brasil, Fernandópolis, Brasil \\ ${ }^{3}$ Centro de Pesquisa em Recursos Hídricos, Instituto de Pesca, APTA-SAA, São Paulo, Brasil \\ ${ }^{4}$ Pesquisador Científico do Instituto de Pesca, São Paulo, Brasil \\ ${ }^{5}$ Aluna PIBIC de Iniciação Científica do Instituto de Pesca, São Paulo, Brasil \\ Email: cthais@pesca.sp.gov.br
}

How to cite this paper: Osti, J.A.S., Carmo, C.F.D., Cerqueira, M., Giamas, M.T.D., Peixoto, A.C. and Mercante, C.T.J. (2019) Recovery of Scenic Beauty of a Lake in Urban Park from Environmental Diagnosis and Implantation of Mitigating Measures. Journal of Water Resource and Protection, 11, 595-605.

https://doi.org/10.4236/jwarp.2019.115034

Received: April 17, 2019

Accepted: May 26, 2019

Published: May 29, 2019

Copyright $\odot 2019$ by author(s) and Scientific Research Publishing Inc. This work is licensed under the Creative Commons Attribution International License (CC BY 4.0).

http://creativecommons.org/licenses/by/4.0/

\section{(c) (i) Open Access}

\begin{abstract}
The city of São Paulo, state of São Paulo/Brazil, with about 12 million inhabitants is considered the largest city in Latin America. Just as in other large metropolises it is devoid of green areas, in this way it is of great socio-environmental importance of the preservation and maintenance of parks and green areas of the municipality. The Fernando Costa Park, known as the Parque da Água Branca, is an urban park located in the central region of the Municipality of São Paulo, and has more than 79 thousand $\mathrm{m}^{2}$ of green area, in a total area of 137 thousand $\mathrm{m}^{2}$. Two lakes, populated predominantly with carp, are inserted in the Park, and are important components of the urban landscape and the patrimony of the city, present landscape function (scenic beauty) and are used to contemplate the environment and leisure of the population. The lakes due to the intense eutrophication process with uncontrolled growth of the phytoplankton presented blue-green coloration, with formations of lumps and foams, low transparency, bad smell and unpleasant visual aspect impairing the visitation of this place. In the first stage of the present research, an environmental diagnosis was carried out and the second stage involved elaboration and implementation of mitigating measures aiming at its restoration. The recovery proposal included the implementation of Artificial Floating Islands (IFAs) aiming at pollution control. After 60 days, it was possible to observe the efficiency of the Eichhornia crassipes populated islands showing that the methodology of phytoremediation was efficient in controlling the eutrophication of urban lakes, guaranteeing the recovery and conservation of
\end{abstract}


the scenic beauty of these places.

\section{Keywords}

Water Quality, Eutrophication, Pollution, Landscape Ecology

\section{Introduction}

The city of São Paulo, state of São Paulo/Brazil, with about 12 million inhabitants is considered the largest city in Latin America [1]. As well as in other large metropolises it is devoid of green areas; in this way it is of great socio-environmental importance of the preservation and maintenance of parks and green areas of the municipality.

Multipurpose parks should be located within or adjacent to urban centers in areas that are easily accessible to the population, predominantly covered by native or exotic vegetation, besides having infrastructure for the development of recreational, cultural, sporting, educational and artistic activities. These environments are subject to anthropic interference, especially in lakes where the impacts generated by human activities cause the decrease of habitat and microhabitat diversity and artificial eutrophication [2]. Urban lakes have an important landscape function, besides providing leisure areas for the population in their environment [3]. Despite the importance of urban lakes, they have been suffering from environmental problems due to demographic advances, with algal blooms occurring in several lakes, causing odors and fish mortality [4] [5]. There are a number of technologies for recovering aquatic ecosystems; recently the use of Artificial Floating Islands (AFIs) has been used as a measure of recovery from lentic (closed) environments. The artificial floating vegetation islands (AFVIs) and built wetlands have been used as eco-engineering technology to mitigate eutrophication and improve water quality by generating little secondary pollution compared to chemical and physical treatment of nutrients [6] [7]. The studies of HUBBARD et al. [8]; HEADLEY \& TANNER [9] and LYNCH et al. [10] have designed AFVIs to float on the water surface with structure floats to stabilize plant roots and underground stems of emergent macrophytes by demonstrating their efficiency in pollution control, such as sewage, streams, storm water runoff, acid mine drainage and reservoirs for water supply. Thus, the objective of the present research was to implant the Artificial Floating Islands (AFIs) technology as a measure of the recovery of the scenic beauty of the landscape of urban lakes located in the Água Branca Park in the city of São Paulo, Brazil, used to contemplate the environment and leisure of the population. This is because the waters of these lakes have a bluish green coloration, with some formations of lump and foam compromising the contemplation of the scenic beauty of the lakes by the public (Figure 1). 


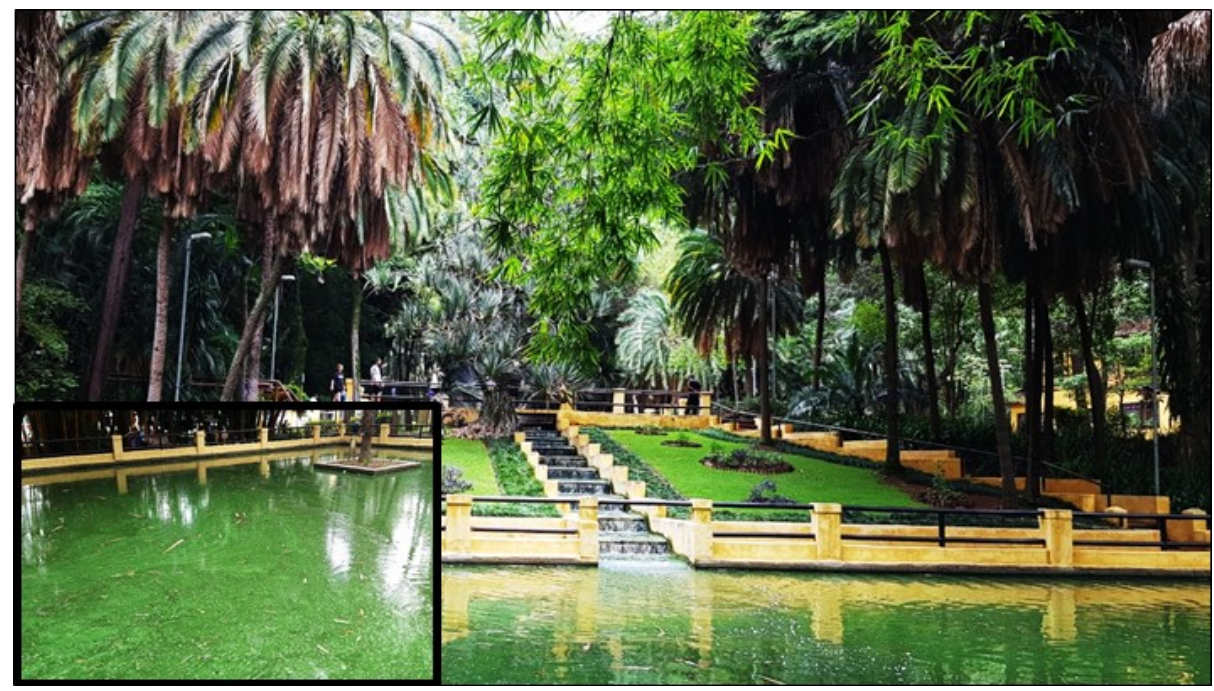

Figure 1. Partial view of the lake of the "Parque da Água Branca". In detail (left side of the figure), bluish green appearance with of foam formations.

\section{Material and Methods}

\subsection{Study Area}

The Fernando Costa Park, known as Parque da Água Branca, is na urban park located in the central region of the Municipality of São Paulo, and has more than 79 thousand $\mathrm{m}^{2}$ of green area, in a total of 137 thousand $\mathrm{m}^{2}$. The park houses different educational and research institutions and presented various cultural activities and educational partners, as well as serving as a space for exhibitions [11]. The two lakes were built in cascade, the first lake presents a source of aeration (fountain) that is fed by the water of the second lake, forming a process of partial feedback (return) of the waters.

The study included two stages: 1) the environmental diagnosis through the limnological characterization of the lakes; 2) the elaboration, implantation and monitoring of mitigating measures to control pollution.

In the first stage of this research, 12 water samples were collected on the sub-surface of 2 lakes populated with carp named: Tank 1 with fountain and Tank 2 without fountain, in November 2017. The collections occurred at 3 different times in 2 consecutive days to evaluate water quality and verify the dynamics of phytoplankton metabolism.

From the results obtained in the first stage it was understood that the bioremediation methodology would be adequate to reach the proposed objectives. Therefore, Eichhornia crassipes confinement network structures were implanted at this stage. Tank 2 was used for the implantation of the structure named Artificial Floating Island (AFI). Tank 2 had an average depth of $0.80 \mathrm{~m}$ (approximately), a surface area of $437 \mathrm{~m}^{2}$ and a volume of about $350 \mathrm{~m}^{3}$, and was chosen to receive water from the Tank 1 and present an area for AFI implantation. The implantation of the AFI occurred in April 2018, being colonized with aquatic macrophytes in the proportion of $2.5 \mathrm{~kg}$ per $\mathrm{m}^{2}$, covering approximately $10 \%$ of 
the area of lake 2. To follow the development of the macrophytes, biometrics were done to estimate the total biomass of the macrophytes. To estimate the biomass, plastic bags were used, digital portable scale of up to $50 \mathrm{~kg}$ and a quadrant $(0.5 \times 0.5 \mathrm{~m})$ made with PVC pipes. The quadrant was randomly played where the macrophytes were confined, collecting the plants within the known area for weighing and biometrics. After the measurements, the macrophytes were returned to the confinement site, this same procedure was repeated for another 2 times.

In step 2, the water samples were collected weekly in the subsurface of the water column, the monitoring lasted 247 days, starting on $03 / 28 / 18$, the IFAs were implanted after 28 days of the beginning of the monitoring.

\subsection{Physical, Chemical and Biological Analyzes of Water}

The $\mathrm{pH}$, water temperature $\left({ }^{\circ} \mathrm{C}\right)$, electrical conductivity $\left(\mathrm{mS} \cdot \mathrm{cm}^{-1}\right)$, turbidity (NTU) and dissolved oxygen $\left(\mathrm{mg} \cdot \mathrm{L}^{-1}\right)$ were measured "in locu" with Horiba W-53 multisonda. The water transparency was estimated "in locu" according to the visual disappearance of the Secchi disk (m). The concentrations of the nutrients: ammonium $\left(\mathrm{mg} \cdot \mathrm{L}^{-1}\right)$, total nitrogen $\left(\mu \mathrm{g} \cdot \mathrm{L}^{-1}\right)$, orthophosphate $\left(\mu \mathrm{g} \cdot \mathrm{L}^{-1}\right)$ and total phosphorus $\left(\mu \mathrm{g} \cdot \mathrm{L}^{-1}\right)$ [12] were determined in the Reference Laboratory in Limnology of the Fisheries Institute. The estimation of phytoplankton biomass was quantified by the concentrations of Chlorophyll a $\left(\mu \mathrm{g} \cdot \mathrm{L}^{-1}\right)$. For the taxonomic analysis of the phytoplankton community, water sample was filtered through a plankton network with a $20 \mu \mathrm{m}$ mesh opening. The samples were stored in a glass vial and fixed in $4 \%-5 \%$ form. The taxonomic analysis was performed using Zeiss-Axioplan 2 optical microscope, in magnifications of 400 and 1000 times.

\subsection{Statistical Analysis}

The descriptive analysis of the data was used to characterize the water quality during the first stage.

The principal component analysis (PCA) was used to evaluate the influence of the implantation of an artificial floating island system (AFI) on the water quality of an urban lake, using program PC-ORD 6.0 for Windows [13]. Data were converted applying $[\log (x+1)]$, except for $\mathrm{pH}$.

\section{Results and Discussion}

\subsection{First Stage}

The mean values of the limnological variables were similar among the lakes (Table 1).

The high concentrations of total phosphorus recorded in lakes Tank 1 and Tank 2, with average values of 92.37 and $99.89 \mu \mathrm{g} \cdot \mathrm{L}^{-1}$, respectively, evidenced the existence of a source of this nutrient and indicate an environment favorable to the growth of planktonic algae. However, the low values of chlorophyll concentrations observed, were contrary to this assertion and also to the aspect of dense and 
Table 1. Mean value and standard deviation for the values of $\mathrm{pH}$, water temperature (T), electrical conductivity (Cond), turbidity (Tur), dissolved oxygen (DO), ion ammonia $\left(\mathrm{NH}_{4}\right)$, total nitrogen, orthophosphate (ORT), total phosphorus (TP) and chlorophyll a, to the lakes of Água Branca Park.

\begin{tabular}{|c|c|c|c|c|c|c|c|c|c|c|}
\hline & $\mathrm{pH}$ & $\mathrm{T}\left({ }^{\circ} \mathrm{C}\right)$ & $\begin{array}{c}\text { Cond } \\
\left(\mathrm{mS} \cdot \mathrm{cm}^{-1}\right)\end{array}$ & Tur (NTU) & $\begin{array}{c}\mathrm{DO} \\
\left(\mathrm{mg} \cdot \mathrm{L}^{-1}\right)\end{array}$ & $\begin{array}{c}\mathrm{NH}_{4} \\
\left(\mathrm{mg} \cdot \mathrm{L}^{-1}\right)\end{array}$ & $\begin{array}{c}\text { TN } \\
\left(\mu \mathrm{g} \cdot \mathrm{L}^{-1}\right)\end{array}$ & $\begin{array}{c}\text { ORT } \\
\left(\mu g \cdot L^{-1}\right)\end{array}$ & $\begin{array}{c}\mathrm{TP} \\
\left(\mu \mathrm{g} \cdot \mathrm{L}^{-1}\right)\end{array}$ & $\begin{array}{c}\mathrm{Cla} \\
\left(\mu \mathrm{g} \cdot \mathrm{L}^{-1}\right)\end{array}$ \\
\hline $\mathrm{T} 1$ & $8.41 \pm 0.17$ & $20.95 \pm 0.54$ & $0.20 \pm 0$ & $51.20 \pm 9.90$ & $9.27 \pm 0.65$ & $0.47 \pm 0.02$ & $607.68 \pm 17.23$ & $26.17 \pm 0.67$ & $92.37 \pm 2.10$ & $14.52 \pm 1.73$ \\
\hline T2 & $8.17 \pm 0.24$ & $21.43 \pm 0.39$ & $0.20 \pm 0$ & $56.30 \pm 9.60$ & $8.52 \pm 0.30$ & $0.50 \pm 0.02$ & $655.09 \pm 13.30$ & $27.92 \pm 0.21$ & $99.87 \pm 1.16$ & $15.82 \pm 1.79$ \\
\hline
\end{tabular}

uniform blue-green coloration observed during the collection. These values may be related to the type of water collection carried out on the subsurface of the water column, since the algae during the blooms are on the surface of the water column, an adaptive process to capture a greater amount of light.

During the taxonomic survey of the phytoplankton community, some cyanobacteria considered to be blooming and potentially toxic were identified in the lake samples (Microcystis aeruginosa (Kützing) Kützing, Microcystis brasiliensis (Azevedo \& Santana) Rigonato, Microcystis wesenbergii (Komárek), Radiocystis fernandoi Komárek \& Komárková-Legnerová). However, it is important to note that the presence of these toxins in the fish ponds can be considered a health risk for organisms inhabiting these sites (ex. fish and birds) due to their toxicity [14], mainly by the bioaccumulation of these toxins by the fishes [15]. MAGALHÃES et al., [16] verified the bioaccumulation of microcystins in tilapia (Tilapia rendalli) that fed on toxic cyanobacteria in Lake Jacarepaguá and confirmed the accumulation and persistence of microcystins in muscle tissues even after the decline of cyanobacteria blooms.

The low renewal of lake water, where part of water exiting the lake 2 spillway is used by the lake 1 fountain, making a water recirculation system, may have provided a stable system, providing competitive advantage for slow growing species, such as flowering cyanobacteria (ex. Cylindrospermopsis, Dolichospermum, Microcystis) [17].

In view of the data presented, we concluded that there was a need for intervention in the lakes with a view to improving the quality of water, seeking not only the scenic beauty of the lakes, but also the quality of life of the organisms existing in these places. Different mitigation measures were proposed: increase of water in intake volume (more important action that would bring fast and permanent results; mechanical cleaning of the surface (it contributes with the scenic beauty, but it is an action that must be done daily); removal of algae by lowering the water column from 4 to $6 \mathrm{~cm}$ (indicated action if it is not possible to increase the volume of incoming water); use of aquatic plants (ex. Eichhornia crassipes) to control the amount of nutrients (biomanipulation technique); use of bioflocos (probiotic) to reduce algae.

In this sense, after verification of all possibilities, it was understood that for the conditions in which the lakes presented technique of biomanipulation would be the most adequate. The biomanipulation technique with the use of constructed wetland (CWs) is alternative to conventional treatments. Constructed Wetlands 
are designed and constructed systems for the treatment of effluents in order to use natural processes in the removal of pollutants [18]. A variation of CWs has been tested more recently and is called Artificial Floating Islands (AFIs). The AFIs are a variation of the treatments systems by CWs aiming to improve the water quality of different pollutant sources, besides being attractive landscape. Therefore, among the mitigating measures described above, biomanipulation using phytoremediation techniques by AFIs seemed to be the most suitable for nutrient control and phytoplankton overgrowth, controlling the eutrophication process and promoting the improvement of the scenic beauty of the landscape park lakes.

\subsection{Second Stage}

Principal Components Analysis (PCA) was used to evaluate the contribution of the implantation of an Artificial Floating Islands system on the water quality of an urban lake (Figure 2; Table 2). The PCA using seven environmental variables,

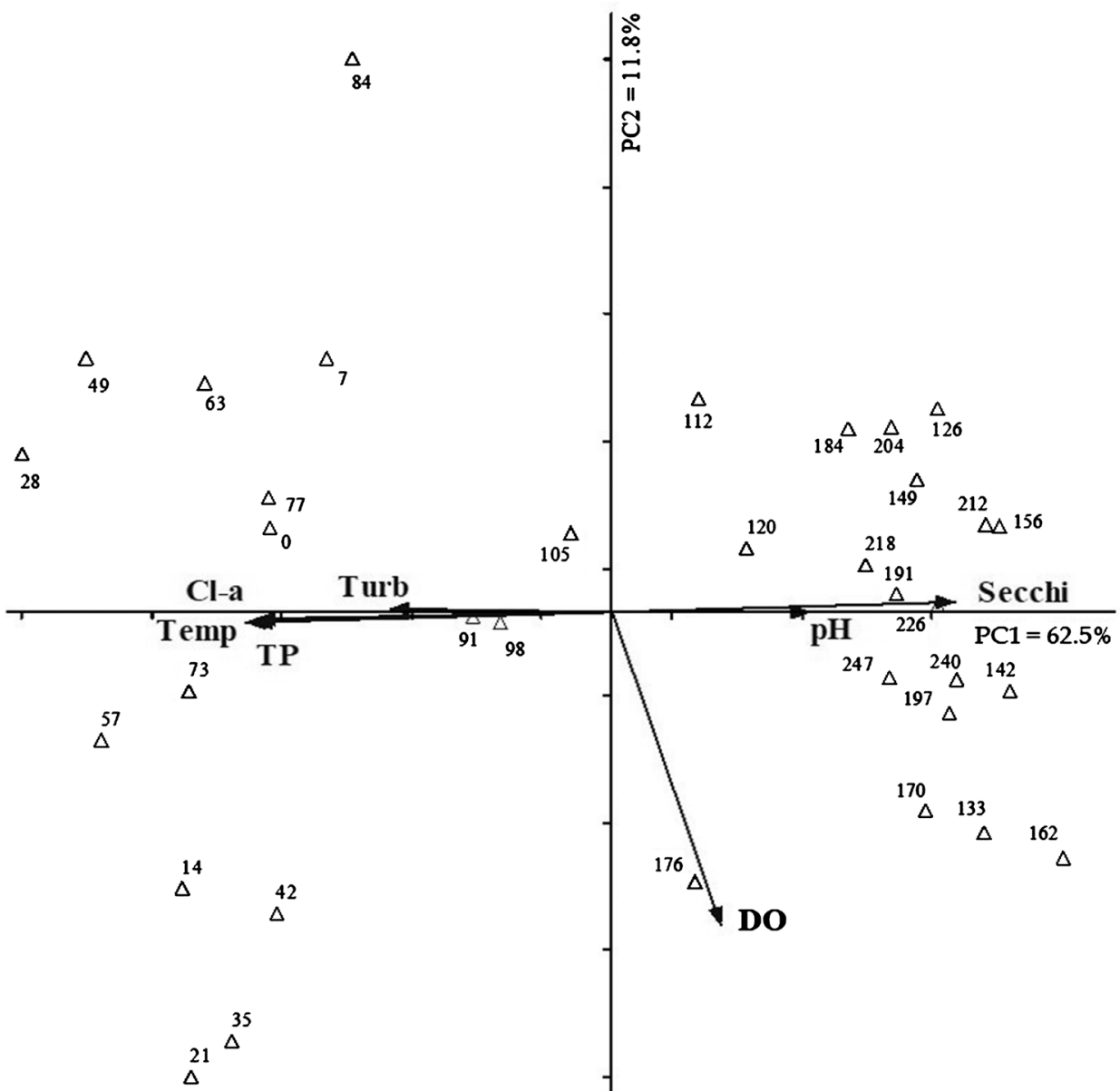

Figure 2. Biplot ordering for the Principal Components Analysis (PCA), between the values of the physical, chemical and biological variables of the water of an urban eutrophic lake before and after the implantation of an Artificial Floating Islands (AFIs) system. For the correlations of the physical, chemical and biological variables of the water with the axes 1 and 2 of ordering, and the respective abbreviations, see Table 2 . 
Table 2. Pearson's correlation coefficient between the physical and chemical variables of the water of an urban lake.

\begin{tabular}{cccc}
\hline & Abbreviations & PC 1 & PC 2 \\
\hline Temperature $\left({ }^{\circ} \mathrm{C}\right)$ & Temp & -0.906 & -0.156 \\
pH & $\mathrm{pH}$ & 0.665 & -0.067 \\
Turbidy $(\mathrm{NTU})$ & Turb & -0.703 & 0.107 \\
Dissolved oxigen $\left(\mathrm{mg} \cdot \mathrm{L}^{-1}\right)$ & DO & 0.495 & -0.847 \\
Total phosphorus $\left(\mu \mathrm{g} \cdot \mathrm{L}^{-1}\right)$ & $\mathrm{TP}$ & -0.898 & -0.155 \\
Chlorophyll $\mathrm{a}\left(\mu \mathrm{g} \cdot \mathrm{L}^{-1}\right)$ & $\mathrm{Cl}-\mathrm{a}$ & -0.892 & -0.132 \\
Secchi disk $(\mathrm{m})$ & Secchi & 0.875 & 0.161 \\
& Explicability & $62.46 \%$ & $11.80 \%$ \\
\hline
\end{tabular}

summarized $74.3 \%$ of the total variability of the data in the first two ordering axes, and was statistically significant for the first axis $(\mathrm{p}<0.01)$. The first axis summarized $62.5 \%$ of the total variability of the data and was the most important to explain the temporal distribution. On the negative side of axis 1, collections were ordered before or shortly after the implantation of the AFIs, these were associated with the highest values of chlorophyll $a$, total phosphorus, water temperature and turbidity. The lower values of these variables and the higher values of $\mathrm{pH}$ and Secchi disk were ordered on the positive of axis 1 .

After 60 days of aquatic plant implantation, it was recorded decrease in the concentrations of total phosphorus and chlorophyll a (Figure 3), the chlorophyll a represents the estimate of the phytoplankton biomass. During this period was also observed improvement in both the visual disappearance of the Secchi disk (Figure 3) and the appearance of the surface water (Figure 4). NABOUT and NOGUEIRA [3] studying four urban lakes, found that local factors such as limnological, geomorphological and landscape characteristics of lakes are strongly associated with structure of the phytoplankton community, often more than seasonal climatic variations.

Different species of macrophytes present different capacity of removal of nutrients from the water. This ability depends on some factors, which vary from species to species, such as biomass production, capacity of store nutrients in biomass, adaptation to local climatic conditions and the physical and chemical characteristics of water [19]. Studies with aquatic macrophytes for treatment of aquaculture effluents, in general, show that these systems efficiently remove nutrients and may still allow their reuse of water in aquaculture activities, such as the work of LIN et al. [20]; SCHULZ et al. [21]; LIN et al. [22]; HENRY-SILVA \& CAMARGO [19]; HENRY-Silva \& CAMARGO [23] and SU et al. [24]. The removal of nutrients was evident in the present research indicating that the Artificial Floating Islands technology was efficient to control the pollution of the studied lakes by improving their water quality. It can also be observed that the 

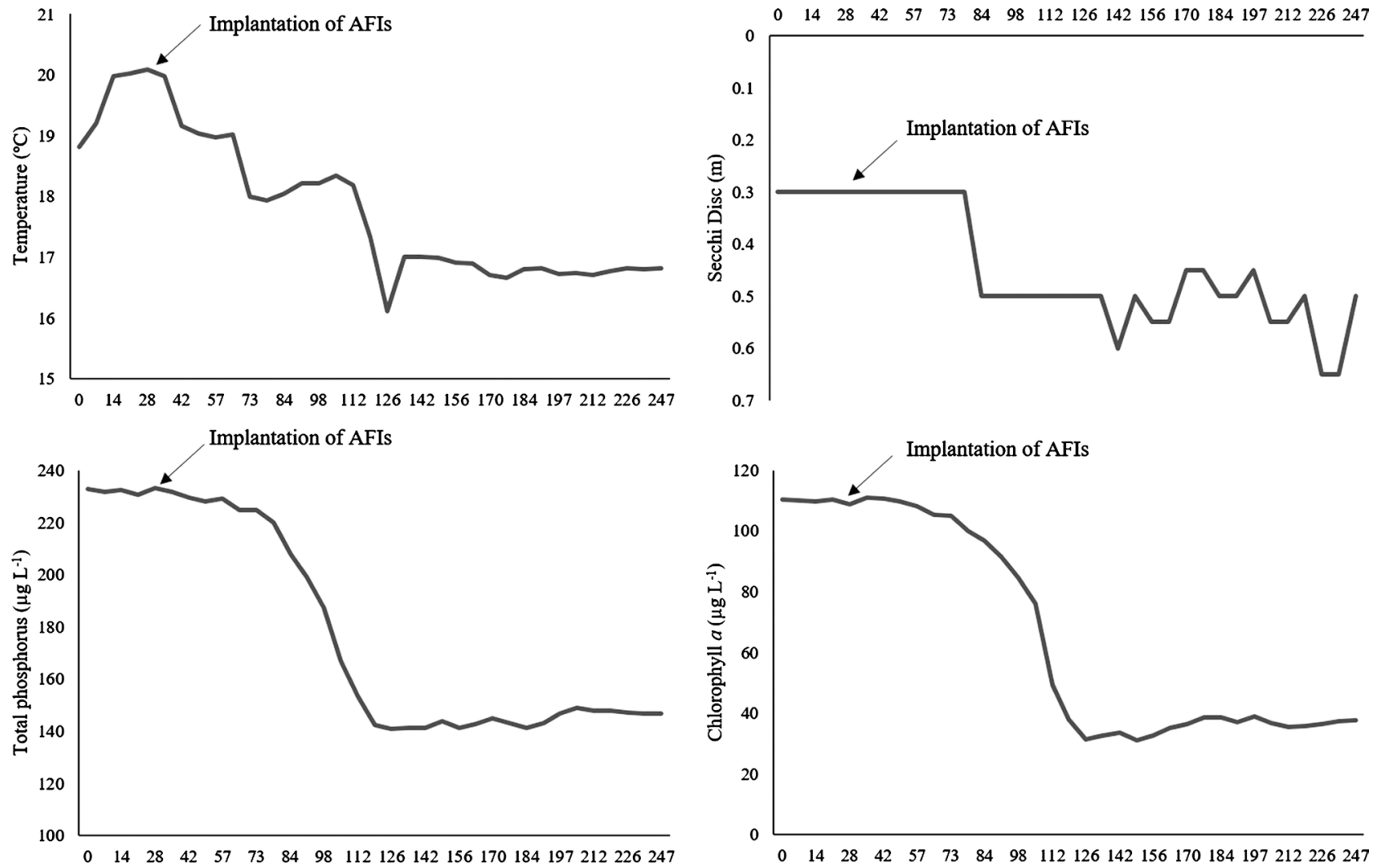

\section{Monitorament period}

Figure 3. Values of the physical, chemical and biological variables of the water of an urban eutrophic lake before and after the implantation of a system of Artificial Floating Islands (AFIs).
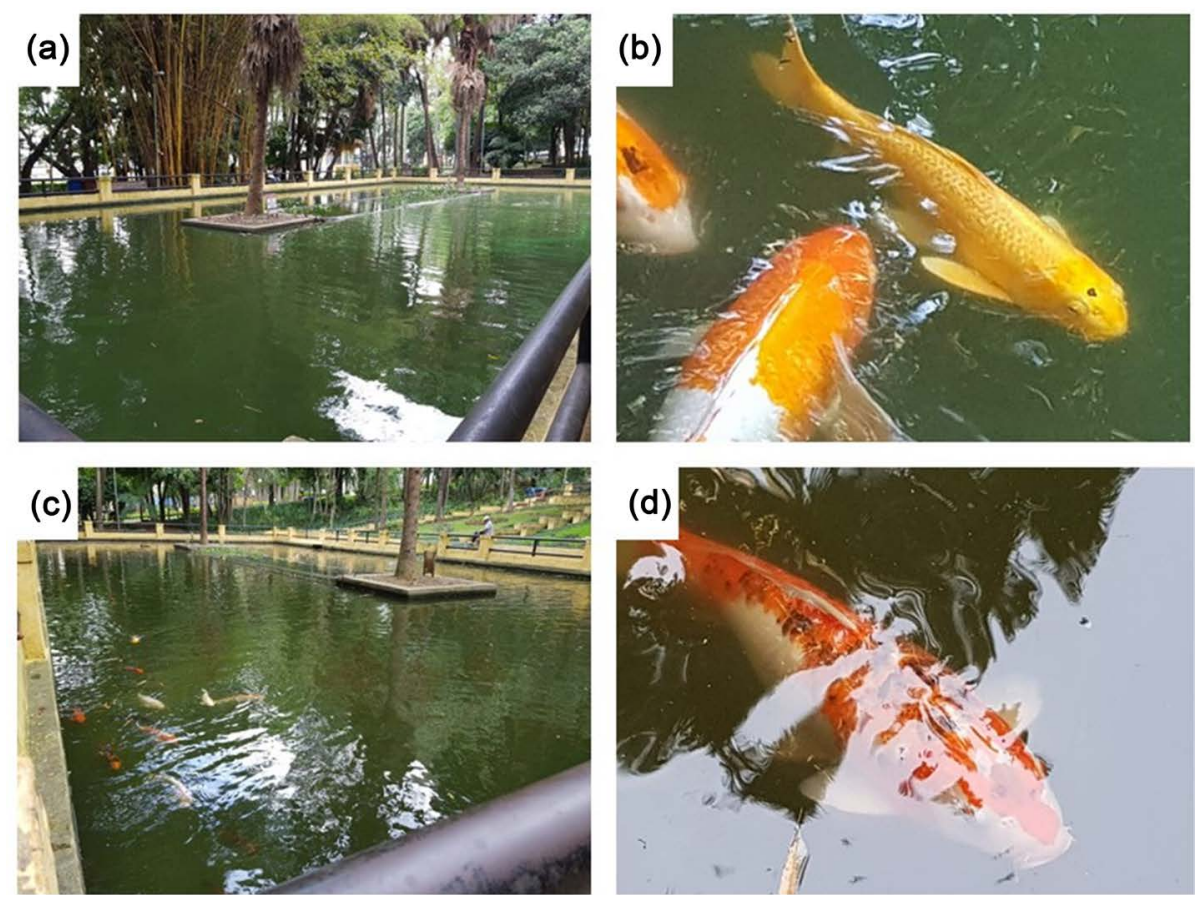

Figure 4. Lake after 60 days of implantation Artificial Floating Islands (AFIs), where ((a) and (c)) = Partial view showing the recovery of scenic beauty of the lake; $((b)$ and $(d))=$ Highlight the transparence of the water. 
macrophyte used in this study Eichhornia crassipes (free floating plant) appeared to be effective in the removal of nutrients from the water as well as the emergent macrophytes used in the studies of HUBBARD et al. [8]; HEADLEY \& TANNER [9] and LYNCH et al. [10].

\section{Conclusion}

The methodology of phytoremediation from the implantation of artificial floating islands populated with Eichhornia crassipes was efficient in controlling the eutrophication of urban lakes, guaranteeing the recovery and conservation of the scenic beauty of these places.

\section{Acknowledgements}

To "Parque da Água Branca" for allowed us the access to your infrastructure. To Fundepag (Agricultural Research Foundation) for financial support.

\section{Conflicts of Interest}

The authors declare no conflicts of interest regarding the publication of this paper.

\section{References}

[1] IBGE (2018) Instituto Brasileiro de Geografia e Estatística. Estimativas de população dos municípios para 2018, Ministério do Planejamento, Orçamento e Gestão. https://cidades.ibge.gov.br/brasil/sp/sao-paulo/panorama

[2] Goulart, M.D. and Callisto, M. (2003) Bioindicadores de qualidade de água como ferramenta em estudos de impacto ambiental. Revista FAPAM, Pará de Minas, 2, $1-9$.

[3] Nabout, J.C. and Nogueira, I.D.S. (2011) Variação temporal da comunidade fitoplanctônica em lagos urbanos eutróficos. Acta Scientiarum Biological Sciences, 33, 383-391. https://doi.org/10.4025/actascibiolsci.v33i4.5955

[4] Tucci, A. and Sant'anna, C.L. (2003) Cylindrospermopsis raciborskii (Woloszynska) Seenayya e Subba Raju (Cyanobacteria): Variação semanal e relação com fatores ambientais em um reservatório eutrófico, São Paulo, SP, Brasil. Revista Brasileira de Botânica, 26, 97-112. https://doi.org/10.1590/S0100-84042003000100011

[5] Oberholster, P.J., Botha, A.M. and Cloete, T.E. (2006) Toxic Cyanobacterial Blooms in a Shallow, Artificially Mixed Urban Lake in Colorado, USA. Lakes and Reservoir: Research and Management, 11, 111-123. https://doi.org/10.1111/j.1440-1770.2006.00297.x

[6] Keizer-Vlek, H.E., Verdonschot, R.C. and Dekkers, D. (2014) The Contribution of Plant Uptake to Nutrient Removal by Floating Treatments Wetlands. Ecological Engineering, 73, 684-690. https://doi.org/10.1016/j.ecoleng.2014.09.081

[7] Zhao, F., Xi, S., Yang, W., Li, J., Gu, B. and He, Z. (2012) Purifying Eutrophic River Waters with Integrated Floating Island Systems. Ecological Engineering, 40, 53-60. https://doi.org/10.1016/j.ecoleng.2011.12.012

[8] Hubbard, R.K., Gascho, G.J. and Newton, G.L. (2004) Use of Floating Vegetation to Remove Nutrients from Swine Lagoon Wastewater. Transactions of the ASABE, 47, 1963-1972. https://doi.org/10.13031/2013.17809 
[9] Headley, T.R. and Tanner, C.C. (2006) Application of Floating Wetlands for Enhanced Stormwater Treatment: A Review. NIWA Client Report: HAM 123, 95.

[10] Lynch, J., Fox, L.J., Owen, J.S. and Sample, D.J. (2015) Evaluation of Commercial Floating Treatment Wetland Technologies for Nutrient Remediation of Stormwater. Ecological Engineering, 75, 61-69. https://doi.org/10.1016/j.ecoleng.2014.11.001

[11] São Paulo, Governo do Estado de São Paulo, Secretaria de Infraestrutura e Meio Ambiente (2019) Parque da Água Branca.

http://www.saopaulo.sp.gov.br/conhecasp/parques-e-reservas-naturais/parque-da-a gua-branca

[12] APHA, AWWA, WPCF (1998) Standard Methods for the Examination of Water and Wastewater. 20th Edition, APHA-American Public Health Association, AWWA-American Water Works Association, and WPCF-Water Pollution Control Federation, Washington DC, 1085 p.

[13] McCune and Mefford, J.J. (1997) PC-ORD Multivariate Analysis of Ecological Data, Version 3.0. Oregon MjM Software Design, $47 \mathrm{p}$.

[14] Romo, S., Soria, J., Fernandez, F., Ouahid, Y. and Bardón-Solá, A. (2012) Water Residence Time and the Dynamics of Toxic Cyanobacteria. Freshwater Biology, 58, 513-522. https://doi.org/10.1111/j.1365-2427.2012.02734.x

[15] Mohamed, Z., et al. (2003) Estimation of Microcystins in the Freshwater Fish Oreochromis niloticus in an Egyptian Fish Farm Containing a Microcystis Bloom. Environmental Toxicology, 18, 137-141. https://doi.org/10.1002/tox.10111

[16] Magalhães, V.F., Soares, R.M. and Azevedo, S.M.F.O. (2001) Microcystin Contamination in Fish from the Jacarepaguá (Rio de Janeiro, Brazil): Ecological Implication and Human Health Risk. Toxicon, 39, 1077-1085.

https://doi.org/10.1016/S0041-0101(00)00251-8

[17] Brasil, J. and Huszar, V.L.M. (2011) O papel dos traços funcionais na Ecologia do fitoplâncton continental. Oecologia Australis, 15, 799-834. https://doi.org/10.4257/oeco.2011.1504.04

[18] Kivaisi, A.K. (2001) The Potencial for Constructed Wetlands for Wastewater Treatment and Reuse in Developing Countries: A Review. Ecological Engineering, 16, 545-560. https://doi.org/10.1016/S0925-8574(00)00113-0

[19] Henry-Silva, G.G. and Camargo, A.F.M. (2006) Efficiency of Aquatic Macrophyte to Treat Nile Tilapia Pond Effluents. Scientia Agricola, 63, 433-438. https://doi.org/10.1590/S0103-90162006000500003

[20] Lin, Y.F., Jing, S.R., Lee, D.Y. and Wang, T.W. (2002) Nutrient Removal from Aquaculture Wastewater Using a Constructed Wetlands System. Aquaculture, 209, 169-184. https://doi.org/10.1016/S0044-8486(01)00801-8

[21] Schulz, C., Gelbrecht, J. and Rennert, B. (2003) Treatment of Rainbow Trout Farm Effluents in Constructed Wetland with Emergent Plants and Subsurface Horizontal Water Flow. Aquaculture, 217, 207-221. https://doi.org/10.1016/S0044-8486(02)00204-1

[22] Lin, Y.F., Jing, S.R., Lee, D.Y., Chang, Y.F., Chen, Y.M. and Shih K.C. (2005) Performance of a Constructed Wetland Treating Intensive Shrimp Aquaculture Wastewater under High Hydraulic Loading Rate. Environmental Polluted, 134, 411-421. https://doi.org/10.1016/j.envpol.2004.09.015

[23] Henry-Silva, G.G. and Camargo, A.F.M. (2008) Tratamento de efluentes de carcinicultura por macrófitas aquáticas flutuantes. Revista Brasileira de Zootecnia, 37, 181-188. https://doi.org/10.1590/S1516-35982008000200002 
[24] Su, Y.M., Lin, Y.F., Jing, S.R. and Hou, P.C. (2011) Plant Growth and the Performance of Mangrove Wetland Microcosms for Mariculture Effluent Depuration. Marin Pollution Bulletin, 62, 1455-1463.

https://doi.org/10.1016/j.marpolbul.2011.04.015 